Lab-scale co-firing of virgin and torrefied bamboo species Guadua angustifolia Kunth as a fuel substitute in coal fired power plants

L.E. Fryda

C.M. Daza Montano J.R. Pels

A.H.H. Janssen

R.W.R. Zwart

May 2014

ECN-W--14-016 


\title{
Lab-scale co-firing of virgin and torrefied bamboo species Guadua angustifolia Kunth as a fuel substitute in coal fired power plants
}

\author{
Lydia Fryda*, Claudia Daza, Jan Pels, Arno Janssen, Robin Zwart \\ Energy Research Centre of the Netherlands (ECN), The Netherlands
}

\section{A R T I C L E I N F O}

\section{Article history:}

Received 30 June 2013

Received in revised form

17 March 2014

Accepted 19 March 2014

Available online 16 April 2014

\section{Keywords:}

Combustion

Guadua

angustifolia

Kunth

Torrefaction

\begin{abstract}
A B S T R A C T
Bamboo is a potential sustainable biomass source for renewable heat and power production as it presents common fuel characteristics with other biomass feedstocks regarding heating value and chemical composition. This paper presents an evaluation of the combustion behaviour of the bamboo species Guadua angustifolia Kunth, virgin as well as torrefied, in blends with coal or pure, comparing with other biomass feedstocks such as wood and herbaceous biomass. The bamboo pre-treatment and the combustion experiments were carried out at dedicated installations at ECN, including a laboratory scale batch torrefaction reactor and a combustion simulation test facility. The results on combustion and co-firing reveal that in terms of fouling, the untreated bamboo shows behaviour closer to herbaceous biomass rather than to wood, with specific fouling factors of wood, bamboo and herbaceous biomass of $0.91 \cdot 10^{-3}, 2.9 \cdot 10^{-3}, 3.1 \cdot 10^{-3} \mathrm{~K} \cdot \mathrm{m}^{2} \cdot \mathrm{W}^{-1} \cdot \mathrm{g}^{-1}$ respectively. Dry torrefaction improves its physical properties by increasing the density and grindability without improving significantly its fouling behaviour while the fouling behaviour of wet torrefied bamboo is similar to woody biomass; the specific fouling factors of dry torrefied and wet torrefied bamboo are $2.4 \cdot 10^{-3}$ and $0.89 \cdot 10^{-3} \mathrm{~K} \cdot \mathrm{m}^{2} \cdot \mathrm{W}^{-1} \cdot \mathrm{g}^{-1}$ respectively. The fouling behaviour of biomass and coal blends lies between the fuels of the blend. Alternative bamboo species were evaluated using the alkali index $A_{i}$ based on their fuel composition. It appears that the fouling behaviour of alternative species is better than for G. angustifolia, therefore these should be further analysed.
\end{abstract}

(c) 2014 Elsevier Ltd. All rights reserved.

\section{Introduction}

\subsection{Bamboo species Guadua angustifolia Kunth: a} novel fuel feedstock

Biomass is expected to play a major role in the transition to sustainable energy production worldwide. It is anticipated that in 2050 biomass could supply $30 \%$ of the total global energy consumption, largely produced via thermal conversion processes as combustion and gasification [1]. The biomass resources will be a combination of residues, various blends of biomass streams, waste and cultivated energy crops.

Anticipating a maximisation of the biomass share in the energy sector, biomass trade will become important, and regulations must be agreed upon so that the various biomass

* Corresponding author. Energy Research Centre of the Netherlands (ECN), P.O. Box 1, 1755 ZG Petten, The Netherlands. Tel.: +31224 564641; fax: +31 224568487.

E-mail addresses: fryda@ecn.nl, lfryda@gmail.com (L. Fryda).

http://dx.doi.org/10.1016/j.biombioe.2014.03.044

0961-9534/@ 2014 Elsevier Ltd. All rights reserved. 
streams are produced in a sustainable way with positive social, economic and environmental impacts. Moreover, in order to simplify biomass trade and supply, the associated logistics and technology need to be optimised [2]. In the frame of identifying and assessing biomass streams, recently bamboo has received special attention because of its easy propagation, vigorous regeneration, fast growth, high productivity and quick maturity. Bamboo is an efficient user of land and produces more biomass per unit area than most tree species [3].

The technical issues related to the final fuel application are of high importance in the assessment of the complete supply chain. The quality and properties of bamboo as a potential biomass source differ within various bamboo species, depending on maturity stage, applied cultivation practices, (e.g. fertilizers application) and production site, factors that affect the specific properties of the material and hence its final application or conversion method.

$G$. angustifolia Kunth is a woody bamboo species, which is native to South America and particularly in the regions of Colombia and Ecuador. G. angustifolia is considered one of the three largest species of bamboo and one of the 20 most used worldwide [4].

In Colombia an area of about $510 \mathrm{~km}^{2}$ is reported to be covered by forest dominated by the bamboo species $G$. angustifolia [5] from which about $90 \%$ is natural forest and $10 \%$ is cultivated. In the coffee region of Colombia (Caldas, Quindío, Risaralda, Valle del Cauca and Tolima), located in the Andes $G$. angustifolia represents an important natural resource traditionally used by farmers to build long-lived products such as houses, furniture, handicrafts, veneers and flooring [6,7]. A significant amount of it is not suitable for manufacturing products and is available from processing sites and from forest and plantations management. This residual material could be used for bioenergy production.

\subsection{Objective of the paper}

Currently there are no studies on the application of bamboo species G. angustifolia in the heat and power sector and the few reported studies on bamboo as energy source [8-11] mainly refer to other bamboo species.

This paper presents results on the suitability of bamboo residues of the species $G$. angustifolia, virgin and thermally pre-treated, as an alternative fuel feedstock for heat and power generation, pure or in blends with coal. The evaluation is based on the fuels' composition and physical characteristics and on their general combustion and ash deposition behaviour in a laboratory scale reactor simulating full-size burners and equipped with specific ash sampling probes.

Combustion is a well-established commercial technology with applications in most industrialised and developing countries. Further development is focused on resolving environmental problems, improving the overall performance with multi-fuel operation and increasing the efficiency of the power and heat cycles. Co-firing is the combustion of more than one fuel in a power plant, a common practice to feed biomass in currently operating power station infrastructures at mass fractions up to $20 \%$ and in some cases reaching $50 \%$ of the total fuel mass fed. This represents a substantial volume of avoided $\mathrm{CO}_{2}$ emissions. Co-firing coal with biomass is a proven technology and well documented in numerous reports and publications [12,13]. It has been promoted through the EU targets for renewable energy and power generation as a relatively low capital cost means of increasing renewable energy generating capacity even in harsh economic conditions and enhancing regional development. Co-firing in fossil fired power stations exceeding $100 \mathrm{MW}$ electric power output takes advantage of their high electrical efficiencies; dedicated biomass combustion at such scales can still be limited due to the local biomass nonavailability.

The fuels tested at lab-scale were samples of a five-yearold bamboo G. angustifolia, virgin as well as thermally pretreated (torrefied), and El Cerrejon coal from Colombia. The co-firing tests were performed in blends with a biomass mass fraction of $20 \%$, as this fraction represents the common practise in co-firing power plants currently. The heat transfer behaviour was monitored on line and ash samples were collected and subjected to elemental analyses. The results were evaluated comparatively to combustion data available for woody and herbaceous biomass species.

\subsection{Biomass properties and pre-treatment options}

In this paper, pre-treatment refers to the techniques used to convert biomass feedstock into biomass fuels. Besides regular forms of pre-treatment like chipping, drying and milling, it also includes dry torrefaction, wet torrefaction and pelletising. The physical properties (particle size, density and moisture content) as well as the chemical composition (elemental, ash and volatile matter) and energy content of a fuel affect its use in a thermal system. Properties such as moisture, density and volatile matter can well be influenced and controlled by established pre-treating options. The use of an alternative feedstock for bioenergy applications requires careful consideration of the effects that feedstock characteristics and composition have on the conversion process.

The quality and properties of bamboo as an energy source differ according to the species, maturity stage, and cultivation practices, e.g. fertilizers application. Bamboo's average proximate analysis and heating value with a mass fraction of ash between 1 and $4 \%$ and a Lower Heating Value (LHV) of 17-18 MJ. $\mathrm{kg}^{-1}$ dry base is comparable to most herbaceous biomass feedstock as well as most agricultural residues, grasses and even woody biomass. Bamboo data mainly other than G. angustifolia, are presented in different sources $[3,8,11,14]$ while other biomass data is presented comparatively in Ref. [15].

In general the physical and chemical properties of virgin bamboo differ compared to those of the fuels used currently (wood pellets, coal) and do not comply with the stringent specifications posed by the thermal conversion processes. This is also the case with most biomass streams, which have fundamentally different properties than coal.

The poor grindability of biomass is one of the limiting factors for the introduction of biomass in thermal power plants on a large scale. For blending biomass in pulverised coal-fired combustion plants or entrained flow gasifiers a small particle size is required. Bamboo, like other herbaceous and woody biomass, is tenacious and fibrous, which makes it 
extremely energy consuming to grind to the desired specifications. Furthermore, biomass characteristics with regard to handling, storage, degradability and energy density are not favourable when compared with coal.

Finally, certain ash properties, such as formation of low melting eutectics due to the high alkali content of herbaceous materials, pose additional technical challenges in the boiler operation, increasing the risk for slagging and fouling In particular the high potassium $(\mathrm{K})$ content of bamboo increases these risks. The high $\mathrm{Cl}$ content of herbaceous and grassy biomass increases the boiler corrosion risk.

Aforementioned problems can be partly offset (1) by blending biomass with coal so as to neutralise the effect of biomass in the boiler (2) applying dry torrefaction (thermal pre-treatment) of biomass in order to enhance the fuel physical properties and finally (3) by removing the alkalis through wet torrefaction.

Dry torrefaction, a mild temperature treatment at $250-320^{\circ} \mathrm{C}$ in the absence of oxygen, is an upgrading technology that increases the biomass energy density and grindability and thus enhances fuel quality and biologic stability [15] while reduces the logistics costs related to transport and storage per energy unit. A very detailed review on the torrefaction technology is presented in Ref. [16].

Wet torrefaction (hydrothermal pre-treatment) is washing at temperature $140-230{ }^{\circ} \mathrm{C}$ under pressure in order to keep water liquid. In this way, biomass undergoes decomposition like in dry torrefaction that opens the biomass structure. The presence of water enables the dissolution of salts. After cooling and pressure release, water is mechanically removed. Together with the water, dissolved components, notably $\mathrm{K}$ and $\mathrm{Cl}$ ions are removed. The partly collapsed structure of the biomass enables very high degrees of dewatering. Typically, the mass fraction of water in the solid residue is less than $40 \%$. Wet torrefaction could be an option for chemically upgrading the fuel by removing the alkalis, benefitting from the advantages of dry torrefaction as well. The wet torrefaction concept is presented in Ref. [17].

\section{Materials and methods}

\subsection{Origin and characterisation of selected fuels}

G. angustifolia samples, not chemically treated, were obtained from a Forest Stewardship Council (FSC) certified forest located in La Esmeralda farm in Montenegro-Quindio, Colombia, in October 2011. The site has the following ecological conditions: an elevation of $1200 \mathrm{~m}$ above sea level, $2 \mathrm{~m} \cdot \mathrm{y}^{-1}$ average precipitation, $24^{\circ} \mathrm{C}$ average temperature and slightly acidic soils (ultisols).

A quantity of $4 \mathrm{t}$ of 5 -year-old bamboo culms was obtained, between 4 and $6 \mathrm{~m}$ length and $20-30 \mathrm{~cm}$ basal diameter and an average wall thickness of $3 \mathrm{~cm}$. The cutting vertical distance above ground level was between 15 and $30 \mathrm{~cm}$. The top section of the culm and leaves were discarded. The moisture mass fraction was an average of $30 \%$.

The culms were transported to a pre-processing site where chips where cut to average dimensions of $5 \mathrm{~cm} \times 5 \mathrm{~cm} \times 3 \mathrm{~cm}$. The chips where then stored and sun dried in a greenhouse for about 6 weeks allowing the material to reach a moisture mass fraction between 10 and 13\%. The dried biomass was then shipped to Rotterdam port in containers.

In order to compare the $G$. angustifolia bamboo composition with other biomass species, a representative wood and an herbaceous crop grown exclusively for fuel production were considered. The herbaceous crop is Cynara cardunculus, which was studied in the frame of a recent EU project DEBCO [18], also identified by the European Biofuels technology platform [19]. C. cardunculus is a perennial, herbaceous, thistle-like crop well adapted to the weather conditions of the Mediterranean, requiring little irrigation, with low moisture mass fraction during harvesting $(<15 \%)$ and a deep-root system that can protect soils from erosion.

The wood samples used in this study were obtained from the Rodenhuize power plant in Belgium, Ghent, firing 100\% wood pellets from the Pacific BioEnergy's production facility situated in the Canadian province of British Columbia.

Colombian coal forms the greatest portion of imported coal to the Netherlands, reaching almost $50 \%$ of the totally imported quantity. The coal samples used for the tests in this study originate from the Cerrejon coal mine in Colombia and were obtained from a Dutch power plant.

The samples were first subjected to ultimate and proximate analyses, and subsequently to dry torrefaction or wet torrefaction before the actual combustion study. The standards used for the characterisations are shown on Table 1.

\subsection{Description of experimental facilities and test procedure}

To determine the influence of torrefaction on the fuel properties of bamboo, an experimental program was employed consisting of a series of lab-scale tests and associated analyses. Tests start with small-scale Thermo Gravimetric Analysis (TGA) experiments (typically 10-20 mg feedstock per experiment), to get a first impression of the thermal behaviour and mass yields at different torrefaction temperatures. The results of these TGA tests then act as input for directly-heated fixed bed batch torrefaction experiments, typically $3-5 \mathrm{~kg}$ per feedstock [16].

The batch size torrefaction reactor is shown in Fig. 1. The reactor consists of a vertical cylinder with and internal diameter (i.d.) of $16 \mathrm{~cm}$ and effective length of $1 \mathrm{~m}$. The bed is divided in three sections to distinguish possible differences in torrefaction behaviour over the bed height. A gas distribution plate supports each section. The reactor is directly heated by supplying preheated nitrogen through a distributor plate at the bottom. In addition, trace heating is applied to compensate for the relatively large heat losses via the reactor vessel for this size of equipment. The off-gases are transported to an incinerator. The gas and tracing temperatures as well as the nitrogen flow are computer controlled and all temperatures, pressures and flows are logged.

Bamboo G. angustifolia was also subjected to wet torrefaction in order to compare its behaviour with dry torrefied material. The wet torrefaction reactor is also shown in Fig. 1. The equipment for wet torrefaction that concern prewashing includes a UniMac industrial washing machine equipped with a bag of $105 \mu \mathrm{m}$ mesh that can hold $5 \mathrm{~kg}$ (dry weight) biomass 
Table 1 - Overview of the standards used for the fuels characterisation.

\begin{tabular}{|c|c|c|}
\hline Analysis & Standard & Title \\
\hline \multicolumn{3}{|c|}{ Proximate analysis (CEN solid biofuels) } \\
\hline Ash Content & EN 14775 & $\begin{array}{l}\text { Solid biofuels - Method for the determination of ash content. Brussels, Belgium: } \\
\text { European Committee for Standardisation; } 2004 \text {. }\end{array}$ \\
\hline Moisture Content & EN $14774-1 / 2$ & $\begin{array}{l}\text { Solid biofuels - Determination of moisture content - Oven dry method - Part 1: } \\
\text { Total moisture - Reference Method. Brussels, Belgium: European Committee for } \\
\text { Standardisation; } 2009 \text {. }\end{array}$ \\
\hline Volatile Matter & EN 15148 & $\begin{array}{l}\text { Solid biofuels - Determination of the content of volatile matter. Brussels, Belgium: } \\
\text { European Committee for Standardisation; } 2010\end{array}$ \\
\hline \multicolumn{3}{|c|}{ Ultimate analysis (CEN solid biofuels) } \\
\hline C, H, N Content & EN 15104 & $\begin{array}{l}\text { Solid biofuels - Determination of total content of carbon, hydrogen and nitrogen - } \\
\text { Instrumental methods. Brussels, Belgium: European Committee for Standardisation; } \\
2011 .\end{array}$ \\
\hline Calorific Value & EN 14918 & $\begin{array}{l}\text { Solid biofuels - Determination of calorific value. Brussels, Belgium: European } \\
\text { Committee for Standardisation; } 2009 .\end{array}$ \\
\hline $\mathrm{S} \& \mathrm{Cl}$ content & BS EN 15289 & $\begin{array}{l}\text { Determination of total content of sulphur and chlorine. Brussels, Belgium: } \\
\text { European Committee for Standardisation; } 2011 .\end{array}$ \\
\hline \multicolumn{3}{|l|}{ Ash elements } \\
\hline $\begin{array}{l}\text { Ash inorganic elements } \\
\text { \& heavy metals }\end{array}$ & NEN 6966 & $\begin{array}{l}\text { Environment - Analyses of selected elements in water, eluates and } \\
\text { destruates - Atomic emission spectrometry with inductively coupled } \\
\text { plasma (ICP-AES). The Netherlands: }\end{array}$ \\
\hline
\end{tabular}

feedstock. The actual wet torrefaction is performed in a Büchi autoclave that can operate with $0.5,2$ or $20 \mathrm{~L}$ vessels. The autoclave has pressure and temperature control, sampling, feeder, but in the current tests feedstock and water were sealed and only temperature was regulated. Contents were cooled before the residual pressure was released. Substantial removal of $\mathrm{K}$ and $\mathrm{Cl}$ was accomplished in the mechanical dewatering, reaching up to $95 \%$ and $82 \%$ of the initial elements concentrations respectively. The sample was air dried and milled for testing.

Given the fact that bamboo will be co-fired in current coal fired power plants it is important to compare its grindability with coal, as this will give an indication of the energy requirement for the grinding at the coal plant and related to that, the potential downgrading of the capacity of the power plant. Grinding experiments were carried out with virgin and torrefied bamboo G. angustifolia and were compared with earlier grinding experiments with bituminous coal and torrefied willow.

The Laboratory Scale Combustor Simulator (LCS) is schematically shown in Fig. 2. It has been designed to simulate pulverised fuel combustion and dry-fed, oxygen-blown entrained flow gasification conditions in terms of particle heating rates, reaction atmosphere, and temperature-time history.

The reactor is equipped with a conical inlet, which decelerates the flue gas and char/ash particles, enabling long residence times in spite of a relative short length. The length of the furnace is $1.2 \mathrm{~m}$. The burner consists of two concentric sub burners, a primary inner burner of internal diameter (i.d.) $1.1 \mathrm{~cm}$ and a secondary outer burner of i.d. $6.1 \mathrm{~cm}$. The

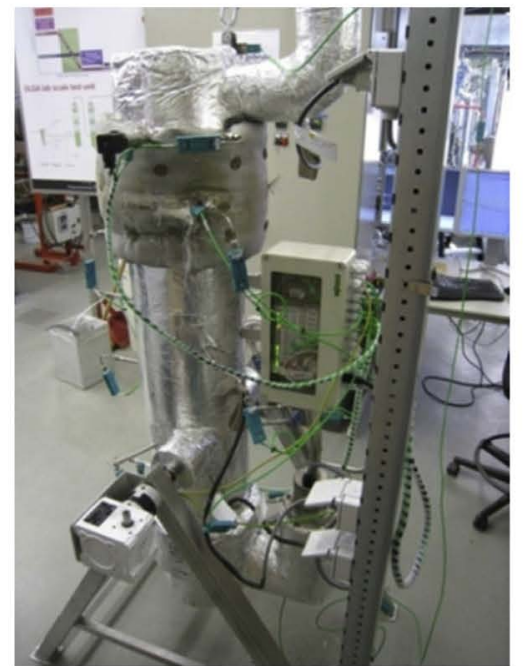

(a)

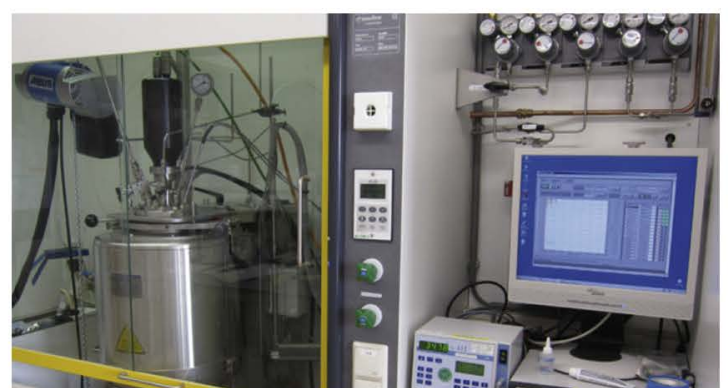

(b)

Fig. 1 - (a) The dry torrefaction batch reactor (b) the wet torrefaction batch reactor. 


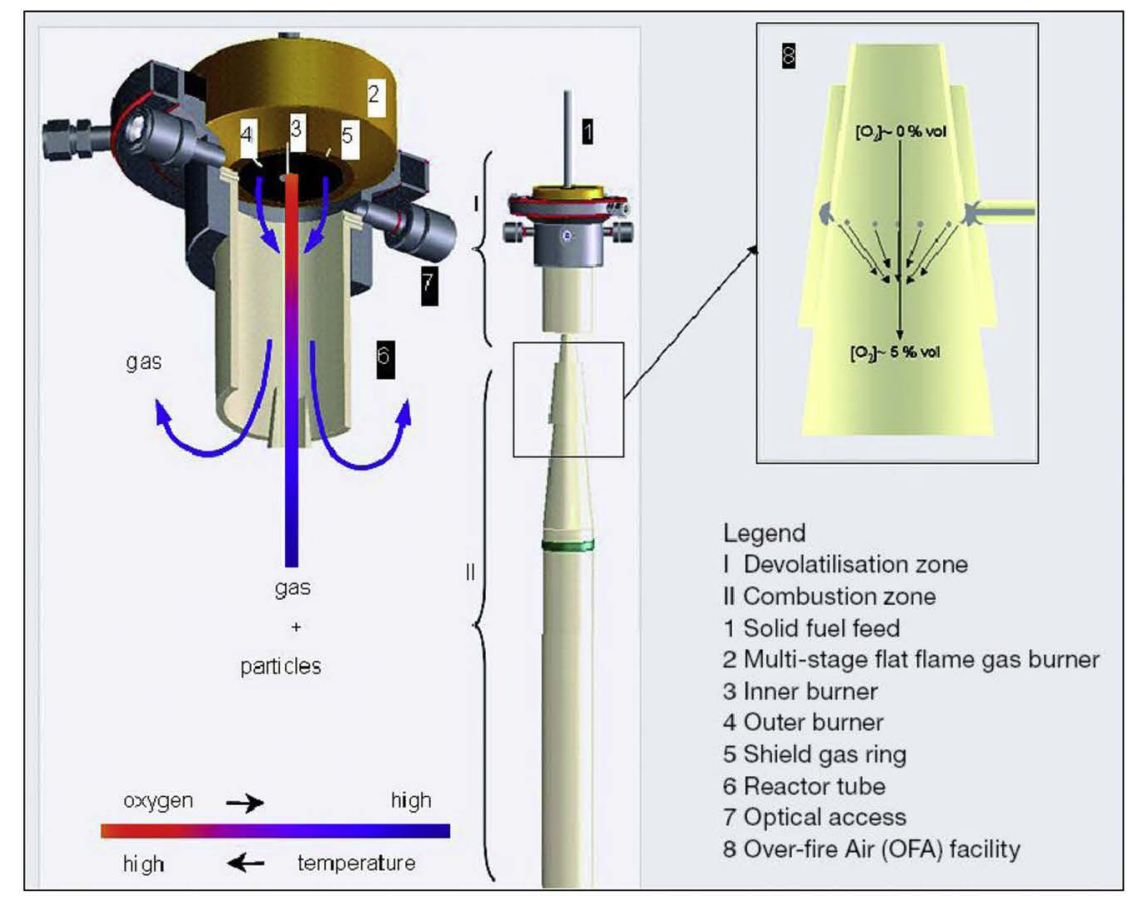

Legend: I Devolatilisation zone, II Combustion/Gasification zone, 1. Solid fuel feed, 2. Multistage flat flame gas burner, 3. Inner burner, 4. Outer burner, 5. Shield gas ring, 6. Reactor tube, 7. Optical access

Fig. 2 - Schematic of ECN's Lab-scale Combustion Simulator (LCS).

resulting gas particle flow is then drawn into the alumina reactor tube of i.d. $7.6 \mathrm{~cm}$ for complete oxidation of the fuel. The ring-shaped, concentric, staged gas burner through which solid fuels are fed is used to simulate the high initial heating rate, resulting in a very rapid pyrolysis and devolatilisation of particles. The outer burner is a flat flame burner that serves as a source for the appropriate reaction atmosphere and pilots the inner burner through which the particles enter the reactor travelling through a premixed Bunsen-like flame. This provides adequate heating rates $\left(10^{-5} \mathrm{~K} \cdot \mathrm{s}^{-1}\right)$ to the high temperature level of e.g. a solid fuel oxidation front $\left(1400-1600{ }^{\circ} \mathrm{C}\right)$, well in range with full-scale pulverised fuel boilers. The staged gas burner provides the possibility to simulate air staging as in low- $\mathrm{NO}_{\mathrm{x}}$ burners and also the presence of specific combustion products such as e.g. $\mathrm{SO}_{2}$.

Typically low particle feed rates of $0.5 \mathrm{mg} \cdot \mathrm{s}^{-1}-1 \mathrm{mg} \cdot \mathrm{s}^{-1}$ are used in order to control the gaseous environment of each particle by means of the imposed gas burner conditions. The influence of either a certain percentage of replacement of the solid fuel (coal) by biomass or the pure biomass combustion on the total heat release fluctuation and oxygen demand is insignificant.

Since the fuel particles are combusted in a premixed gas flame, the flue gas stream is not generated by the combusting fuel but mainly by the combusting gas $\left(\mathrm{CH}_{4}\right.$ and $\left.\mathrm{CO}\right)$. The flue gas composition therefore cannot be directly interpreted but gives a trend and can be evaluated comparatively with other tests carried out under the same conditions.
The flame temperature is controlled by the flat flame gas burner, and external heaters control the temperature profile in the reactor. The calculated average gas velocity is $1.1 \mathrm{~m} \cdot \mathrm{s}^{-1}$ in the vicinity of the conical burner, and reduces to $0.2 \mathrm{~m} \cdot \mathrm{s}^{-1}$ when the gas enters the main reactor cylinder. Velocity calculations are based on the gas inlet volume flows, assuming laminar flow and taking into account the reactor geometry and the axial gas temperature profile. A suction pump that operates at a constant volume flow rate assures for homogeneous velocities and therefore isokinetic conditions in the reactor.

Boiler tube fouling studies are carried out by applying a horizontal probe placed at $85 \mathrm{~cm}$ from the burner. This probe, with i.d. of $1.5 \mathrm{~cm}$, simulates the gas/particles flow around a single boiler tube in the convective section of a boiler. It is provided with a ring shaped heat-flux sensor installed on the horizontal tube as well as with a detachable tubular deposition substrate. The surface temperature of the probe is controlled by an air-cooling system.

Deposition samples can be collected in either the sensor area or the detachable probe surface. When the sensor is used, on-line data on the influence of the deposit on the effective heat flux trough the tube wall are collected allowing calculating the fouling factor, which is inversely proportionate to the overall heat transfer coefficient, given in equation (2). The ash collected on the sensor is subjected to analyses. It is also possible to collect ash on a detachable substrate and then fix the ash sample with epoxy for further electronic microscope 
analyses. The carbon-in-ash was determined in all ash samples.

The combustion test tests include:

(1) Deposition and heat flux monitoring tests

(2) Ash sampling from the sensor and the fine ash filter

\subsection{Combustion trials with G. angustifolia}

\subsubsection{Test conditions and test plan}

All tests were carried out under the same LCS configuration concerning the gas burner operation, with an air stoichiometry lambda $(\lambda) 20 \%$, and a constant fuel feed rate of $1.1 \mathrm{mg} \cdot \mathrm{s}^{-1}$ to secure proper fuel conversion. Milled biomass and coal was used in the fraction of $90-125 \mu \mathrm{m}$. One test series was carried out with a torrefied fuel fraction of $180-250 \mu \mathrm{m}$ in order to monitor the effect of particle size on combustion and burnout properties. The test plan shown in Table 2 was set up so as to address the objective of evaluating the bamboo pellets as a coal substitute in power plants.

\subsubsection{Indicators for the combustion behaviour of fuels}

The behaviour of fuels can be evaluated based on various indicators, namely:

(a) Deposition propensity based on the ash captured on the probe, which is linked to the ash composition but also, depends on the reactor dynamics.

(b) Fouling factor, which is directly linked to the thermal conductivity of the deposit.

(c) Indices based only on fuel composition and not on tests, e.g. fouling index.

Item (c) will be discussed in Section 3.3.

2.3.2.1. Deposition propensity. The ash samples collected in the horizontal probe during the experiments were weighed. In order to assess the deposition behaviour of the fuel, the deposition propensity DP is introduced, defined as the percentage of the ash collected on the deposit probe, $m_{\mathrm{dep}}$, divided by the total ash content in the fuel fed, $m_{\text {ash }}$, based the proximate analysis of the fuel and the fuel fed.

$\mathrm{DP}=\frac{m_{\mathrm{dep}}}{m_{\mathrm{ash}}}(\%)$

The ash mass $m_{\text {dep }}$ is the ash deposited on the horizontal probe that was collected after the end of the experiment. The deposition propensity provides insight into the inherent

\section{Table 2 - Overview of the tests.}

\begin{tabular}{lcl} 
Fuels & $\begin{array}{c}\text { Blend mass } \\
\text { fraction } \%\end{array}$ & Particle size $(\mu \mathrm{m})$ \\
\hline G. angustifolia (untreated) & 100 & $90-125$ \\
G. angustifolia (torrefied) & 100 & $90-125 \& 180-250$ \\
G. angustifolia (wet torrefied) & 100 & $90-125$ \\
Colombian coal & 100 & $90-125$ \\
Colombian coal/ & $80 / 20$ & $90-125$ \\
$\quad$ G. angustifolia (torrefied) & & \\
\hline
\end{tabular}

deposition characteristics of the different fuels, as it normalises the ash deposition in relation with the fuel ash content. The deposition propensity takes into account the fuel ash content, but relies on experimental data as well, rather than only the ash composition.

2.3.2.2. Fouling behaviour. Based on the heat flux data measured on-line by the sensor probe, the fouling factor $R_{\mathrm{f}}$ of the tested fuels can be estimated, which corresponds to the heat transfer resistance of the tested fuel:

$R_{\mathrm{f}}=\left(\frac{1}{U_{1}}-\frac{1}{U_{0}}\right)=\frac{T_{g}-T_{c}^{1}}{H F_{1}}-\frac{T_{g}-T_{c}^{0}}{H F_{0}}$

$\mathrm{R}_{\mathrm{f}}$ - fouling factor, $\mathrm{K} \cdot \mathrm{m}^{2} \cdot \mathrm{W}^{-1}$ (heat transfer resistance)

$U_{1}$ - ash deposits heat transfer coefficient after time $t=t_{1}$, $\mathrm{W} \cdot \mathrm{K}^{-1} \cdot \mathrm{m}^{-2}$

$U_{0}-$ initial heat transfer coefficient after $t=t_{0}=0$, $\mathrm{W} \cdot \mathrm{K}^{-1} \cdot \mathrm{m}^{-2}$

$\mathrm{T}_{\mathrm{g}}$ - flue gas temperature, $\mathrm{K}$,

$\mathrm{T}_{\mathrm{C}}$ - coolant medium temperature in the deposition probe, $\mathrm{K}$,

$\mathrm{HF}_{1}$ - heat flux to the sensor after time $t=t_{1}, \mathrm{~W} \cdot \mathrm{m}^{-2}$

$\mathrm{HF}_{\mathrm{O}}$ - initial heat flux to the sensor $\mathrm{t}=\mathrm{t}_{0}=0, \mathrm{~W} \cdot \mathrm{m}^{-2}$

Sub index 1 refers to the conditions after elapsed time $t=t_{1}$, while sub index 0 refers to the initial conditions $t=t_{0}=0$.

\section{Results and discussion}

\subsection{Fuel composition and characterisation}

The results of the fuels' characterisation are shown in Table 3. The proposed specifications for the industrial wood pellets are given in the document Initiative Wood Pellets Buyers (IWPB) [20] as a relevant reference concerning biomass fuels, so a comparison within the fuels can be made directly. These pellet specifications do not include all elements and the proposed values are not yet binding for the users. Power plant operators decide for every fuel separately whether they accept to co-utilise it. For the elements $\mathrm{Cl}, \mathrm{S}, \mathrm{K}$ and $\mathrm{Na}$ their oxide equivalents $\mathrm{SO}_{3}, \mathrm{Na}_{2} \mathrm{O}$ and $\mathrm{K}_{2} \mathrm{O}$ were calculated and presented as mass fraction \% in the ash, in order to facilitate the results discussion in section 3 concerning the limit values of EN 450 on fly ash utilisation in the cement industry.

The chlorine (Cl) content of the untreated G. angustifolia is higher than for wood $\left( \pm 150 \mathrm{mg} \cdot \mathrm{kg}^{-1}\right)$, and less than for a representative herbaceous crop. The potassium $(\mathrm{K})$ concentration in $G$. angustifolia with a value of $9.2 \mathrm{~g} \cdot \mathrm{kg}^{-1}$ is much higher than in wood and coal. Most other ash forming elements concentrations are lower than in herbaceous crops and comparable to wood with a notable exception for silicon (Si). The high $\mathrm{K}$ and $\mathrm{Si}$ content of the unprocessed $\mathrm{G}$. angustifolia must be kept in mind concerning their potential to form ash deposits and reduce heat transfer in the boiler surfaces. 
Table 3 - Proximate, ultimate and ash analysis of the tested fuels.

\begin{tabular}{|c|c|c|c|c|c|c|c|}
\hline & $\begin{array}{c}\text { El } \\
\text { Cerrejon } \\
\text { coal }\end{array}$ & $\begin{array}{l}\text { G. angustifolia } \\
\text { (5 years) }\end{array}$ & $\begin{array}{l}\text { Dry torrefied } \\
\text { G. angustifolia } \\
\text { (5 years) } \\
255^{\circ} \mathrm{C}\end{array}$ & $\begin{array}{l}\text { Wet torrefied } \\
\text { G. angustifolia } \\
\text { (5 years) }\end{array}$ & $\begin{array}{c}\text { Representative } \\
\text { herbaceous crop } \\
\text { (Cynara } \\
\text { cardunculus) }\end{array}$ & $\begin{array}{l}\text { Representative } \\
\text { wood }\end{array}$ & $\begin{array}{c}\text { Initiative wood pellets } \\
\text { Buyers: Industrial } \\
\text { wood pellets } \\
\text { specification }\end{array}$ \\
\hline $\begin{array}{l}\text { Moisture mass } \\
\text { fraction } \% \\
105^{\circ} \mathrm{C}\end{array}$ & 4.5 & 9 & $0.3^{a}$ & $0.06^{a}$ & 11 & 7.1 & $<10$ \\
\hline \multicolumn{8}{|c|}{ Proximate analysis (mass fraction \%, dry fuel basis) } \\
\hline $\begin{array}{l}\text { Ash } \\
815^{\circ} \mathrm{C}\end{array}$ & 10.5 & 5.1 & 6.9 & 4.5 & 5.1 & 1.44 & - \\
\hline $\begin{array}{l}\text { Ash } \\
550^{\circ} \mathrm{C}\end{array}$ & - & 5.7 & 7.6 & 4.9 & 6.2 & 2.16 & $1-3$ \\
\hline $\begin{array}{l}\text { Volatile } \\
\text { matter }\end{array}$ & 33.5 & 75 & 65 & 76 & 75 & 80 & \\
\hline $\begin{array}{l}\mathrm{HHV} \\
\left(\mathrm{MJ} \cdot \mathrm{kg}^{-1}\right) \\
\text { Ultimate analys }\end{array}$ & $\begin{array}{l}26.7 \\
\text { sis (mass fre }\end{array}$ & $\begin{array}{c}18.8 \\
\text { action (\%), dry fue }\end{array}$ & el basis) & 20.3 & 19.0 & 20.0 & $>16.5$ \\
\hline C & 69 & 47 & 51 & 50 & 42 & 50 & \\
\hline $\mathrm{H}$ & 4.6 & 5.9 & 5.5 & 5.8 & 5.5 & 6.1 & \\
\hline $\mathrm{N}$ & 1.11 & 0.30 & 0.34 & 0.27 & 0.55 & 0.40 & $0.5-1.5$ \\
\hline $\mathrm{s}$ & 0.810 & 0.080 & 0.068 & 0.026 & 0.015 & 0.030 & $0.15-0.4$ \\
\hline $\mathrm{SO}_{3}(\%)^{\mathrm{b}}$ & 2.020 & 0.210 & 0.17 & 0.065 & 0.037 & 0.075 & \\
\hline $\mathrm{O}$ & 12 & 43 & 35 & 44 & 43 & 44.2 & \\
\hline \multicolumn{8}{|c|}{ Ash composition (mg $\mathrm{kg}^{-1}$, dry fuel basis) } \\
\hline $\mathrm{Na}( \pm 7)$ & 319 & 3 & 3.5 & 29.4 & 4100 & 191 & \\
\hline $\mathrm{Na}_{2} \mathrm{O}(\%)^{\mathrm{b}}$ & 0.0430 & 0.0004 & 0.0005 & 0.0041 & 0.5535 & 0.0260 & \\
\hline $\operatorname{Mg}( \pm 1)$ & 916 & 218 & 169 & 15.9 & 1500 & 404 & \\
\hline $\mathrm{Al}( \pm 4)$ & 9210 & 10 & 9 & 20 & 160 & 474 & \\
\hline $\mathrm{Si}( \pm 90)$ & 25712 & 12731 & 25906 & 20121 & 650 & 1331 & \\
\hline $\mathrm{P}( \pm 15)$ & 54 & 482 & 513 & 50.7 & 910 & 122 & \\
\hline $\mathrm{K}( \pm 20)$ & 1588 & 9902 & 9271 & 510 & 12000 & 984 & \\
\hline $\mathrm{K}_{2} \mathrm{O}(\%)^{\mathrm{b}}$ & 0.19 & 1.20 & 1.10 & 0.06 & 1.44 & 0.12 & \\
\hline $\mathrm{Ca}( \pm 20)$ & 1695 & 252 & 242 & 396 & 12000 & 1919 & \\
\hline $\operatorname{Ti}( \pm 8)$ & 470.0 & 0.5 & 0.5 & 0.7 & 8.6 & 96.0 & \\
\hline $\mathrm{Mn}( \pm 6)$ & 42 & 2 & 2 & 2.1 & 17 & 66 & \\
\hline Fe $( \pm 4)$ & 5347 & 14 & 11 & 26 & 110 & 301 & \\
\hline $\mathrm{Zn}( \pm 1)$ & 20 & 6 & 4 & 3 & 13 & 25 & $<200$ \\
\hline $\mathrm{Pb}( \pm 20)$ & 2 & 0 & 0 & 0.33 & 4 & 8 & $<20$ \\
\hline $\operatorname{Sr}( \pm 5)$ & 28 & 2 & 3 & 1 & 59 & 11 & \\
\hline $\mathrm{Ba}( \pm 5)$ & 85.0 & 2.5 & 3.5 & 1.3 & 26.1 & 29.0 & \\
\hline $\mathrm{Cl}( \pm 20)$ & 236 & 1395 & 949 & 253 & 2800 & 153 & \\
\hline $\mathrm{Cl}(\%)^{\mathrm{b}}$ & 0.024 & 0.140 & 0.095 & 0.025 & 0.280 & 0.015 & $0.03-0.1 \%$ \\
\hline
\end{tabular}

${ }^{\text {a }}$ Moisture measured on the final product.

b $\mathrm{S}, \mathrm{K}, \mathrm{Na}$ and $\mathrm{Cl}$ expressed as $\mathrm{SO}_{3}, \mathrm{Na}_{2} \mathrm{O}, \mathrm{K}_{2} \mathrm{O}$ and $\mathrm{Cl}$ mass fraction in ash (\%).

The moisture content shown in Table 3 is the actual moisture of the fuels as received in the laboratory. The moisture of the virgin fuels (wood, G. angustifolia, coal, C. cardunculus) is the as-received value. The moisture content of the torrefied (wet and dry) fuels is the content of the final product.

\subsection{Lab-scale torrefaction trials}

Based on the lab-scale tests carried out, a rough energy balance can be estimated. The dry torrefaction process produces material with $90 \%$ of the original energy preserved. The $10 \%$ of the energy input that is missing is consumed by heating and drying. For running a full-scale installation, the process layout is important, but this is beyond the scope of the paper. For virgin material milling and pelleting requires about $3 \%$ of the energy content of the material, mostly consumed by the milling. After torrefaction, the energy is mostly consumed by the pelleting. The significantly lower grinding power consumption requirement for the torrefied material is illustrated in Fig. 3, which shows the effect of the torrefaction temperature on the grindability of the different biomass species expressed as the ratio of power consumed to the fuel energy content flow. The results for coal and willow were obtained from previous torrefaction tests at $260{ }^{\circ} \mathrm{C}[15,21]$, after which the grindability was comparable with coal. On the basis of the current milling tests it was decided to use 5 year old $G$. angustifolia bamboo torrefied at $255{ }^{\circ} \mathrm{C}$ for the combustion tests as at this temperature the grindability of the bamboo is in the same range as coal [22].

For wet torrefaction, the energy balance is more complex to estimate. About $30 \%$ of the energy in the original material is washed out, but it is recovered by way of digestion. The biogas can be combusted in a gas engine. The power produced is sufficient to run all equipment and to have a surplus of 


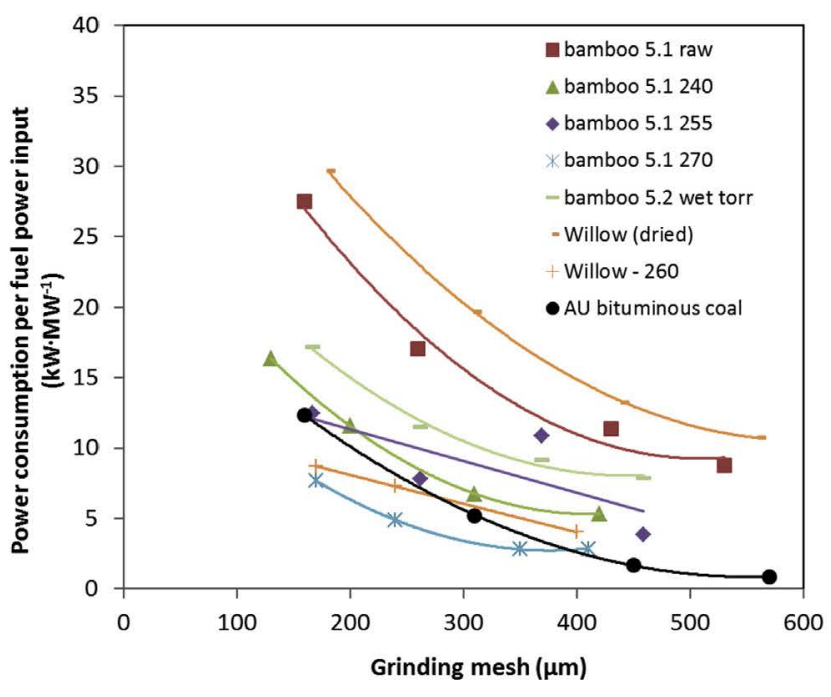

Fig. 3 - Effect of torrefaction temperature and particle size of untreated and torrefied bamboo on grindability.

electricity. The waste heat is enough for heating the wet torrefaction and subsequently the digester. Exact numbers depend on the feedstock and the layout of the process, but this is beyond the scope of the paper. There have been no precise or published calculations for bamboo or reeds.

\subsection{Combustion trials}

\subsubsection{Fuel conversion and emission behaviour}

The results on the carbon in ash in the samples analysed are shown in Table 4. The $\mathrm{CO}, \mathrm{NO}_{\mathrm{x}}, \mathrm{CO}_{2}$, and $\mathrm{O}_{2}$ levels in the flue gas were monitored continuously, average state operation values are shown in Table $4 . \mathrm{SO}_{2}$ emissions were not measured.

The CO levels were in all tests low, slightly higher than the levels of $\mathrm{CO}$ emissions when the reactor operated on the methane (pilot) flame without fuel, indicating high fuel conversion. Although the carbon levels were low in all ash samples, a small difference was found between two size fractions of torrefied bamboo, namely the carbon-in-ash was a bit higher in the larger particle fraction, which also may explain the higher deposition propensity, suggesting the existence of more char in the deposit.

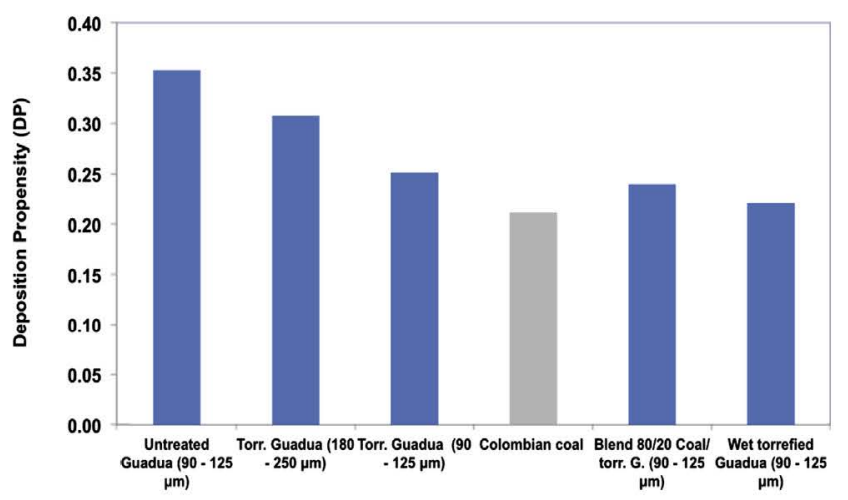

Fig. 4 - Deposition propensity for the tested fuels and blends.

The NO emission reduction due to co-firing is minimal; practically there seems no effect due to co-firing. The replacement of $20 \%$ of the coal mass with biomass was probably not enough to observe considerable $\mathrm{NO}_{\mathrm{x}}$ reductions. However the formation and emissions of $\mathrm{NO}_{\mathrm{x}}$ is a very complex process not discussed in this paper. $\mathrm{NO}_{\mathrm{x}}$ emissions are not only linked with the $\mathrm{N}$ content of the fuel but also depend on the combustor design and fluid dynamics prevailing. As $\mathrm{NO}_{\mathrm{x}}$ emissions did not seem to be reduced by the addition of biomass, a $\mathrm{NO}_{\mathrm{x}}$ reduction system in the power plant is still necessary to comply with emission limits.

\subsubsection{Indicators for the combustion behaviour of fuels}

The deposition propensities as calculated from equation (1) are shown in Fig. 4.

It seems that the deposition propensity of the virgin biomass (Fig. 4) is higher compared to the treated (dry torrefied) biomass, however conclusions cannot be drawn at this point. One could notice that even when subjected to dry torrefaction, at temperatures well below the combustion temperature, the chemical composition of the fuel ash can change, with respect to volatile species like $\mathrm{Cl}$ and $\mathrm{K}$, as shown from the composition in Table 2. There we can notice that $\mathrm{K}$ and $\mathrm{Cl}$ are lower in dry torrefied material than in raw material, despite the fact that a mass loss has occurred. In contrast, the content of $\mathrm{Si}$, an element known to be less volatile, is increased after dry torrefaction but this tendency is not

Table 4 - Carbon in ash and flue gas composition for the test cases.

\begin{tabular}{|c|c|c|c|}
\hline Fuel/Blend & $\begin{array}{c}\text { C in ash } \\
\text { (mass fraction \%, dry) } \\
\text { deposited ash/Filter ash }\end{array}$ & $\begin{array}{c}\text { Flue gas } \\
\left(\mathrm{CO}_{2} / \mathrm{O}_{2}: \text { volume \%) }\right. \\
\left(\mathrm{CO}: \mu \mathrm{L} \cdot \mathrm{L}^{-1}\right)\end{array}$ & $\mathrm{NO}_{\mathrm{x}}\left(\mu \mathrm{L} \cdot \mathrm{L}^{-1}\right)$ \\
\hline $\begin{array}{l}\text { G. angustifolia } \\
\text { (torrefied, 180-250 } \mu \mathrm{m} \text { ) }\end{array}$ & $1.9 / 2.7$ & $10.7 \% / 3.5 \% / 2$ & 90 \\
\hline G. angustifolia (untreated, $90-125 \mu \mathrm{m}$ ) & $1.4 / 1.3$ & $10.5 \% / 3.5 \% / 3$ & 85 \\
\hline Colombian coal & $1.2 / 2.2$ & $10.2 \% / 3.5 \% / 3$ & 140 \\
\hline $\begin{array}{l}\text { Coal/G. angustifolia } \\
\text { blend, } 80 / 20\end{array}$ & $1.3 / 3.7$ & $10.7 \% / 2.9 \% / 1$ & 137 \\
\hline $\begin{array}{l}\text { G. angustifolia } \\
\text { (torrefied, 90-125 } \mu \mathrm{m} \text { ) }\end{array}$ & $1.4 / 1.3$ & $10.3 \% / 3.1 \% / 4$ & 85 \\
\hline $\begin{array}{l}\text { G. angustifolia } \\
\text { (wet torr., 90-125 } \mu \mathrm{m} \text { ) }\end{array}$ & $1.4 / 1.5$ & $8.8 \% / 3.5 \% /-$ & 80 \\
\hline
\end{tabular}




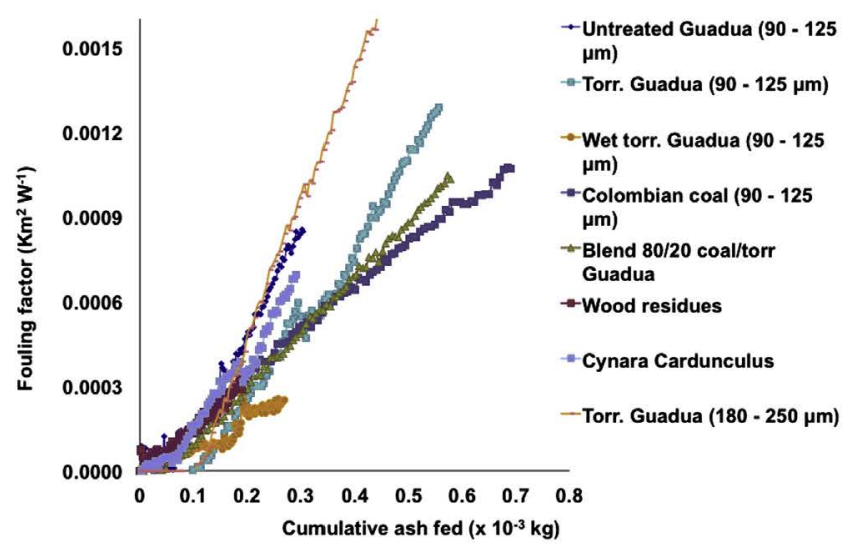

Fig. 5 - Fouling factors versus accumulated feed rate for the tested fuels under air combustion conditions.

confirmed for $\mathrm{Ca}$ or Fe, also known to be not volatile. The increase in total ash content in the case of dry torrefaction, appears to be only due to $\mathrm{Si}$, which may indicate that the inhomogeneity of the material is of the same order (or higher) than the effect of dry torrefaction. Finally, the behaviour of the blend seems to be corresponding to the blend percentage, in other words proportional to the behaviour of the individual fuels that this blend consists of.

Fig. 4 gives some information on the effect of particle size on deposition behaviour, for the size range $180-250 \mu \mathrm{m}$ in comparison with 90-125 $\mu \mathrm{m}$ for the torrefied bamboo. A higher deposition propensity can therefore come from larger char particles, which increase the mass of deposit by adding char particles (rather than ash particles). In addition to this, one may notice that the carbon in ash was slightly increased in the sampled deposited ash of this higher particle size, while its ash composition was slightly closer to the original fuel, as will be shown later, both facts indicating that the increased deposition in the case of larger particle sizes could be due to char deposited rather than larger ash particles. It has to be noted however that it could simply be the fact that smaller particles will better follow the flue gas flow whereas the momentum of larger particles cause more particles to bounce onto the sensor tube.

The fouling factors calculated from equation (2) are depicted in Fig. 5 as a function of the ash accumulated on the deposition probe. The moment at which fuel feeding started was considered as the start of the heat flux measurement. In all cases the heat flux, surface temperatures, cooling airflow rate and furnace temperatures were at steady state during measurement. In order to compare the fuel behaviour of $G$. angustifolia (virgin or pre-treated) with other previously used biomass, also the fouling behaviour of an average woody biomass and C. cardunculus, are shown in the same graph, the wood representing a commonly used woody biomass, and the herbaceous biomass a novel proposed feedstock [18].

Fig. 5 indicates that the fouling behaviour of virgin bamboo G. angustifolia is more severe than of the dry torrefied $G$. angustifolia in accordance with the deposition tendency
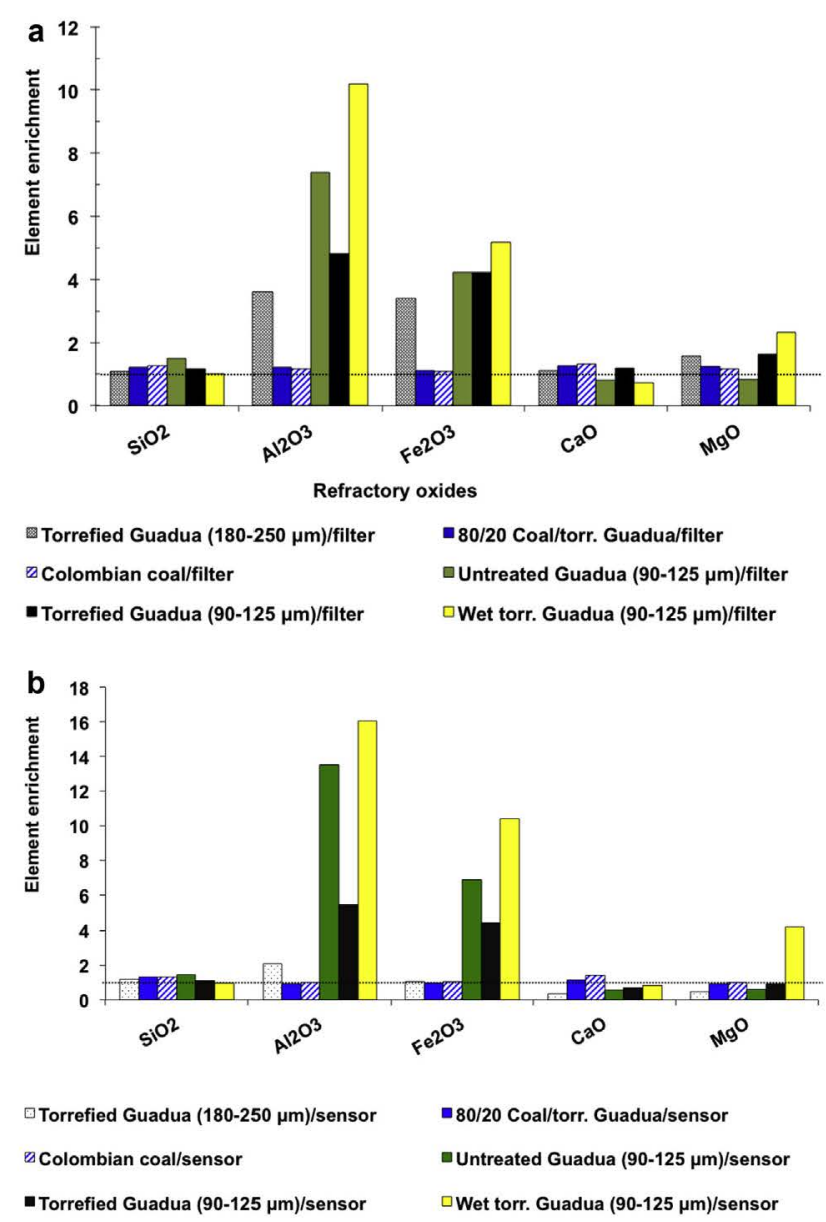

Fig. 6 - a \& b: Element enrichment (enrichment factor) of refractory oxides of the filter ash (fine ash) and the sensor ash (deposited ash).

results. In relation with an average herbaceous fuel, it seems that virgin $G$. angustifolia behaves similar, as the fouling factor lines are close, however the wet torrefied G. angustifolia shows fouling behaviour comparable to representative clean wood, as the two lines representing the fouling factors of wood and wet torrefied G. angustifolia are close. The coarser sample of dry torrefied $G$. angustifolia seems to show the highest fouling behaviour, probably due to deposited unburnt char particles or larger ash particles, as discussed. It must be noted that the absolute values depicted in this graph do not have a practical value, however their relative position to each other gives a comparative evaluation of the fouling behaviour of these fuels.

A final remark is that the slope of the fouling factor lines in Fig. 5, called Specific fouling factor, is given in equation (3) as the ratio between the fouling factor value and the corresponding accumulated ash value. This value can be used to give a fast comparison of the fouling behaviour among fuels in a table format. 


\subsection{Chemical composition analysis: element enrichment - ash analyses of deposited and fine ash}

The behaviour and distribution of the inorganic ash elements was defined and quantified by performing a mass balance including the mass and the composition of the fuels and the ash samples obtained from (1) the deposited ash and (2) the fly ash obtained from the filter, which represents the ash that was not deposited on the probe. The element concentrations in the sampled ash are presented as their ratio to the element concentration in the original fuel; this ratio is called elements enrichment or enrichment factor $(E F)$. Therefore, the original fuels take the value $E F=1$ for each of their elements (reference value).

In this paragraph some main conclusions are discussed based on the results presented in the following Figs. 6 and 7.

\subsubsection{Coal and coal blend}

$\mathrm{S}$ and $\mathrm{Cl}$ were depleted in the ash, indicating their release in the gas phase, possibly due to alkali sulphation. The relatively small $\mathrm{S}$ concentration and the high $\mathrm{Si}$ content of the fuel ash may indicate that most of the $\mathrm{K}$ and $\mathrm{Na}$ in the deposit is expected to form alkali silicates rather than bind with $\mathrm{S}$, which is released in the gas phase. Alkalis seem to remain in the ash instead of entering the gas phase but not to a level that they enrich the ash compared to the original fuel ash.
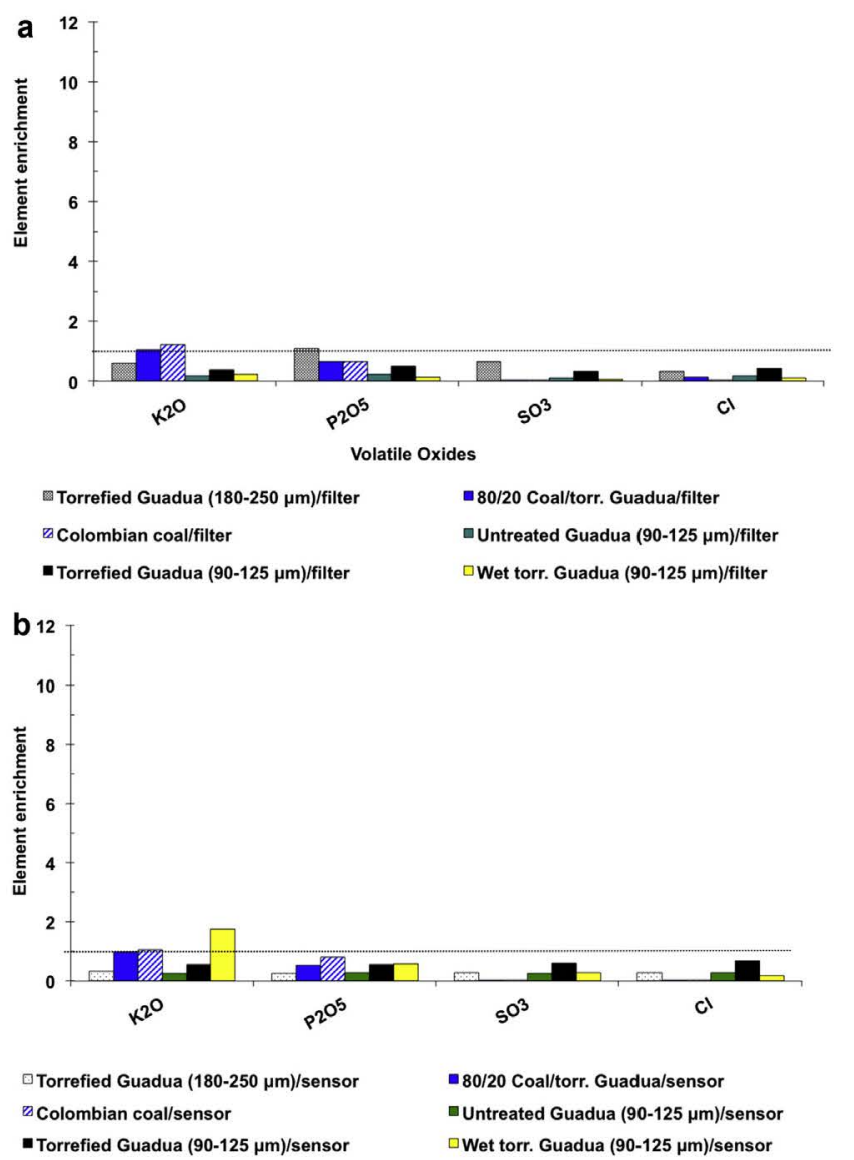

Fig. 7 - a \& b: Element enrichment (enrichment factor) of volatile oxides in the filter (fine ash) and the sensor (deposited ash).

\subsubsection{Untreated \& torrefied biomass}

No enrichment for $\mathrm{K}$ and $\mathrm{Cl}$ is observed, while only negligible amounts of $\mathrm{S}$ were detected in the ash of untreated and torrefied biomass. $\mathrm{K}$ enters the gas phase probably due to the chlorine (Cl) present, which is facilitating the volatilisation of elements that would otherwise deposit. From the refractory elements $\mathrm{Al}$ and $\mathrm{Fe}$ are present in the ash; the rest of the main oxides are detected at the same levels as in the original fuels before combustion (no element enrichment).

According to the standard EN 450-1 for the use of pulverised fly ash in concrete (Fly ash for concrete: Definition, specifications and conformity criteria, BS EN 450-1:2012, Brussels, Belgium: European Committee for Standardisation; 2012), the relevant limits are Chloride $<0.1 \%$ mass fraction, $S$ as $\mathrm{SO}_{3}<3.0 \%$ mass fraction, and Alkali as $\mathrm{Na}_{2} \mathrm{O}$ equivalent $\left(\mathrm{Na}_{2} \mathrm{O}+0.658 \mathrm{~K}_{2} \mathrm{O}\right)<5 \%$ mass fraction. Fig. 7 shows that their concentration in the filter ash is less than it was in the fuel. By comparing the values given in the standard with the $\mathrm{SO}_{3}, \mathrm{Cl}$ and alkali oxide mass fractions (\%) shown in Table 2 it can be concluded that the fly ash from the combustion of this particular bamboo species could be considered in the cement industry; however a full evaluation of the fly ash according to EN 450-1:2012 was not carried out.

The depletion of volatile elements in both the filter and the sensor ash in the case of dry torrefied material indicates their entering the flue gas phase, possibly ending on the economiser tubes, the FGD unit or exiting in the flue gas stream. Gas cleaning measures may have to be taken in case of using $G$. angustifolia, dry torrefied or virgin, using dry electrostatic precipitators (ESP), wet electrostatic precipitators for gaseous acid pollutant control and fabric filters (FF) for high removal efficiency. Removal of $\mathrm{HCl}$ from flue gas may be necessary, using hydrated lime injected into the boiler [23]. Concerning the wet torrefied biomass, it has already undergone some serious depletion of $\mathrm{K}$ and $\mathrm{Cl}$ in the pre-treatment phase, therefore very low concentrations are expected in the flue gas.

\subsection{Evaluation of alternative bamboo species based on their fuel composition}

Four other bamboo species, Guadua amplexifolia, Bambusa vulgaris, Dendrocalamus strictus, and Chusquea subulata were subjected to proximate, ultimate and ash element analyses in order to carry out a preliminary evaluation based on their compositions. The results are shown in Table 5.

The fouling behaviour of fuels in a combustion facility is evaluated based on indicators that conclude experimental findings and on fuel composition indicators. It is mainly the experimental results that can be extrapolated in the larger scale while the indicators based only on fuel composition give rather an overall and general estimation of the expected fouling behaviour. We already presented and discussed the Deposition Propensity and the Fouling Factor for the tested fuels and blends based on lab-scale results. An evaluation of the combustion behaviour of the bamboo species presented in Table 5, that were not tested at lab scale, based on their fuel ash composition is attempted here.

The fouling index $\left(F_{\mathrm{i}}\right)$, referenced in Refs. [24,25] is calculated as the product of the base-to-acid ratio of the fuel ash 
Table 5 - Fuel composition of other bamboo species.

\begin{tabular}{|c|c|c|c|c|}
\hline Bamboo species & Guadua amplexifolia & Dendrocalamus strictus & Bambusa vulgaris & Chusquea subulata \\
\hline Moisture mass fraction $\%$ & 11 & 9.6 & 9.3 & 11 \\
\hline \multicolumn{5}{|c|}{ Proximate analysis (\% mass, dry fuel basis) } \\
\hline Ash mass fraction $\% 815^{\circ} \mathrm{C}$ & 3.8 & 5.6 & 2.7 & 6.9 \\
\hline Ash mass fraction $\% 550{ }^{\circ} \mathrm{C}$ & 4.9 & 6.5 & 2.9 & 7.1 \\
\hline Volatile matter mass fraction $\%$ & 74 & 75 & 76 & 74 \\
\hline $\mathrm{HHV}\left(\mathrm{MJ} \cdot \mathrm{kg}^{-1}\right)$ & 18.78 & 18.73 & 19.05 & 18.56 \\
\hline \multicolumn{5}{|c|}{ Ultimate analysis (mass fraction \%, dry fuel basis) } \\
\hline C & 47 & 47 & 48 & 46 \\
\hline $\mathrm{H}$ & 6.0 & 5.9 & 6.1 & 5.4 \\
\hline $\mathrm{N}$ & 0.8 & 1.2 & 0.6 & 0.8 \\
\hline S & 0.2 & 0.2 & 0.1 & 0.1 \\
\hline $\mathrm{O}$ & 43 & 41 & 43 & 42 \\
\hline \multicolumn{5}{|c|}{ Ash composition (mg. $\mathrm{kg}^{-1}$, dry fuel basis) } \\
\hline $\mathrm{Na}( \pm 7)$ & 12 & 14 & 5 & 13 \\
\hline $\operatorname{Mg}( \pm 1)$ & 290 & 1617 & 225 & 482 \\
\hline $\mathrm{Al}( \pm 4)$ & 13 & 5 & 6 & 21 \\
\hline $\mathrm{Si}( \pm 90)$ & 6209 & 21105 & 7570 & 20260 \\
\hline$P( \pm 15)$ & 1283 & 1786 & 892 & 2766 \\
\hline$K( \pm 20)$ & 16402 & 3656 & 6907 & 7158 \\
\hline $\mathrm{Ca}( \pm 20)$ & 380 & 346 & 215 & 379 \\
\hline $\mathrm{Ti}( \pm 8)$ & 1 & 0 & 0 & 1 \\
\hline $\operatorname{Mn}( \pm 6)$ & 7 & 7 & 4 & 9 \\
\hline $\mathrm{Fe}( \pm 4)$ & 20 & 22 & 17 & 54 \\
\hline $\mathrm{Zn}( \pm 1)$ & 22 & 33 & 8 & 32 \\
\hline $\mathrm{Pb}( \pm 20)$ & $<0.6$ & $<0.6$ & $<0.6$ & 2 \\
\hline $\operatorname{Sr}( \pm 5)$ & 2 & 1 & 1 & 5 \\
\hline $\mathrm{Ba}( \pm 5)$ & 1 & 1 & 1 & 3 \\
\hline $\mathrm{Cl}( \pm 20)$ & 859 & 438 & 213 & 1205 \\
\hline
\end{tabular}

oxides, $R_{\mathrm{B} / \mathrm{A}}$, and $\mathrm{Na}_{2} \mathrm{O}$ (expressed as mass fraction $\%$ in the ash)

$R_{B / A}=B / A$

$F_{\mathrm{i}}=\mathrm{R}_{\mathrm{B} / \mathrm{A}} \times \mathrm{Na}_{2} \mathrm{O}(\%$, mass fraction in ash $)$

This index is considered to not be easily applicable to biomass fuels, because their ash compositions form different chemical systems compared to the coal ash. The majority of the potassium in coal ashes is present as a constituent of the clay minerals, and is not considered to be available for release by volatilisation in the flame to the same extent as in most biomass materials. In biomass, typically potassium is the dominant alkali metal and present in a form available for release by volatilisation. Therefore, it was chosen to not base our evaluation on the fouling index, as it would lead to misleading results.

A more useful number is the alkali index [26], which has become popular in recent years as a threshold indicator for fouling and slagging for biomass fuels. Even though all biomass fuels exhibit fouling behaviour, the rate and extend differs depending on their quite variable ash composition and ash content. The alkali index, in this paper described as $A_{i}$, expresses the quantity of alkali oxide in the fuel per unit of fuel energy $\left(\mathrm{kg} \cdot \mathrm{GJ}^{-1}\right)$ :

$A_{\mathrm{i}}=(\mathrm{HHV})^{-1} \cdot w_{\mathrm{a}} \cdot\left(w_{\mathrm{K} 2 \mathrm{O}}+w_{\mathrm{Na} 2 \mathrm{O}}\right)$

where HHV is the higher heating value of the fuel expressed in $\mathrm{GJ} \cdot \mathrm{kg}^{-1}$ (the value obtained from a bomb calorimeter, the higher heating value at constant volume, dry basis), $w_{\mathrm{a}}$ is the mass fraction (dimensionless) of ash in the fuel, $\mathrm{w}_{\mathrm{K} 2 \mathrm{O}}$ and
$w_{\mathrm{Na} 2 \mathrm{O}}$ are the mass fractions (dimensionless) of the alkali oxides $\mathrm{K}_{2} \mathrm{O}$ and $\mathrm{Na}_{2} \mathrm{O}$ in the ash. Jenkins et al. [26] have suggested that for alkali index values above $0.17 \mathrm{~kg} \cdot \mathrm{GJ}^{-1}$ fouling is probable, and for values above $0.34 \mathrm{~kg} \cdot \mathrm{GJ}^{-1}$ fouling is virtually certain to occur. The threshold levels are determined principally on the basis of experience.

Other indicators proposed in literature are the so-called critical mole ratios of the fuels: $\mathrm{Ca} / \mathrm{S}, \mathrm{S} / \mathrm{Cl}, \mathrm{Al} / \mathrm{Cl}$ [27].

Table 6 shows comparatively the specific fouling factors (Specific f.f) as obtained from Fig. 5, described and explained in equation (3) of paragraph 3.3.2, the alkali index for all tested fuels and novel bamboo species and finally the three critical molar ratios presented in this section. Knowing the fouling behaviour of the tested fuels in the given experimental set-up allows for a first evaluation of the effectiveness of the proposed indicators. Based on this evaluation, some comments for the other bamboo species can be given as to their expected fouling behaviour.

By observing the values of the Specific fouling factor obtained from Fig. 5 shown in Table 6 we can say that the alkali index $A_{i}$ is in line with the fouling behaviour of the tested fuels. The highest values of Specific f.f and $A_{i}$ refer to the untreated bamboo, the values are lower for the torrefied bamboo, and even more for the wet torrefied bamboo. We can thus assume that a first, preliminary evaluation of the nontested fuels is possible based on their fuel composition. From the untested fuels, G. amplexifolia seems to be the worst candidate based on its $A_{i}$ values. Given the fact that values $A_{i}$ within the range $0.17-0.34 \mathrm{~kg} \cdot \mathrm{GJ}^{-1}$ indicate low to medium fouling, the species $D$. strictus may prove better than the rest. 
Table 6 - Alkali index, critical molar ratios and specific fouling factors of tested fuels and alternative bamboo species.

\begin{tabular}{|c|c|c|c|c|c|}
\hline & $\begin{array}{c}A_{i} \\
\mathrm{~kg} \cdot \mathrm{GJ}^{-1}\end{array}$ & $\mathrm{Ca} / \mathrm{S}$ & $\mathrm{S} / \mathrm{Cl}$ & $\mathrm{Al} / \mathrm{Cl}$ & $\begin{array}{c}\text { Specific } \text { f. f } \\
\mathrm{K} \cdot \mathrm{m}^{2} \cdot \mathrm{W}^{-1} \mathrm{~g}^{-1}\end{array}$ \\
\hline \multicolumn{6}{|l|}{ Tested fuels } \\
\hline G. angustifolia & 0.67 & 0.24 & 0.68 & 0.01 & $2.9 \cdot 10^{-3}$ \\
\hline $\begin{array}{l}\text { Dry torrefied } \\
\text { G. angustifolia. }\end{array}$ & 0.52 & 0.28 & 0.81 & 0.01 & $2.4 \cdot 10^{-3}$ \\
\hline Coal El Cerrejon & 0.09 & 0.17 & 37.2 & 50.6 & $1.5 \cdot 10^{-3}$ \\
\hline Blend Coal/ & 0.17 & 0.19 & 29.9 & 40.5 & $1.8 \cdot 10^{-3}$ \\
\hline \multicolumn{6}{|l|}{$\begin{array}{l}\text { Dry Torr. } \\
\text { G. angustifolia } \\
80 / 20\end{array}$} \\
\hline $\begin{array}{l}\text { Wet torrefied } \\
\text { G. angustifolia }\end{array}$ & 0.03 & 1.20 & 1.18 & 0.11 & $0.89 \cdot 10^{-3}$ \\
\hline Wood & 0.09 & 5.9 & 1.86 & 4.02 & $0.91 \cdot 10^{-3}$ \\
\hline $\begin{array}{l}\text { C. cardunculus } \\
\text { Other bamboo } \\
\text { species }\end{array}$ & 0.88 & 6.4 & 0.59 & 0.07 & $3.1 \cdot 10^{-3}$ \\
\hline G. amplexifolia & 0.94 & 0.16 & 2.47 & 0.02 & - \\
\hline B. vulgaris & 0.41 & 0.32 & 2.75 & 0.04 & - \\
\hline D. strictus & 0.21 & 0.18 & 3.77 & 0.01 & - \\
\hline Ch. subulata & 0.49 & 0.17 & 1.16 & 0.02 & - \\
\hline
\end{tabular}

However, even though $B$. vulgaris shows $A_{i}$ values that are not very favourable, it is a promising fuel in terms of ash composition as it conforms to the IWPB guidelines especially concerning $\mathrm{Cl}$ and ash concentration (Tables 3 and 5).

Concerning the other three indicators $\mathrm{Ca} / \mathrm{S}, \mathrm{S} / \mathrm{Cl}, \mathrm{Al} / \mathrm{Cl}$ [27], a high $\mathrm{Ca} / \mathrm{S}$ ratio $(>3)$ indicates effective $\mathrm{SO}_{2}$ autocapture, which is the case in wood and C. cardunculus, probably due to the very low $\mathrm{S}$ concentrations, but not in the bamboo species under consideration. The surplus of $\mathrm{S}$ is available for other reactions and potentially emitted as $\mathrm{SO}_{2}$.

In the case of the $\mathrm{S} / \mathrm{Cl}$ ratio, values $<4$ indicate corrosion risk, while values $>4$ indicate effective sulphation of alkalis, releasing $\mathrm{Cl}$ in the gas phase. This the case only for the coal and coal blend, hence $\mathrm{Cl}$ is not expected in the deposits, reducing therefore the corrosion risk.

A high $\mathrm{Al} / \mathrm{Cl}$ ratio indicates low fouling problems because of enough alumina silicates that bind (neutralise) alkalis towards effective alkali aluminium silicate formation; this is the case only in the coal and coal blend, thus implying, risk of fouling for the other blends.

The analysis above forecasts that some species of bamboo can be suitable fuels, while others are not advisable. In any case, bamboo in general seems to be a good replacement for clean wood when alkalis and chlorine are removed as in wet torrefaction.

However, further detailed analysis based on fuel composition need to be carried out as a follow-up research step, such as for example, chemical fractionation for the ash composition, in order to define more precisely which elements and to what extend they are available for reactions, or whether they are inert and despite the high concentrations they do not affect the melting behaviour of ash. Alkalis and $\mathrm{Cl}$ are mobile elements and are expected to be present in variable concentrations in bamboo feedstock. Especially biomass alkalis are highly mobile in contrast to coal alkalis; therefore the abovementioned indices need to be evaluated carefully.
It must be noted that no absolute conclusions based on these indicators can be drawn because fouling (ash deposition) behaviour also depends on boiler lay-out and dynamics [28], on the actual combustion conditions and the particle size distribution of the fuels, factors which are not taken into account in these indicators and that may affect final ash release and behaviour. Finally, it is important to compare the fuel values with pellet specifications (most relevant: Initiative Wood Pellets Buyers - IWPB), which is a decisive factor whether a fuel would be further considered. In that case, $B$. vulgaris seems a good candidate due to low $\mathrm{Cl}$ and low ash content, even if the fuel indicators at this stage seem not that favourable. However, the IWPB criteria were developed for wood pellets; other biomass types may need to comply with other sets of criteria. A comparison with the IWPB criteria is only indicative.

\section{Conclusions}

This paper presents the results of the fuel characterisation, pre-treatment (dry and wet torrefaction) and combustion of the five-year old bamboo species G. angustifolia received from a plantation in Colombia, in blends with coal and in comparison with woody and herbaceous biomass fuels. G. angustifolia presents comparable fuel characteristics with other woody and herbaceous biomass feedstocks, regarding heating value and chemical composition, however the alkali content in the virgin material is quite high. It is tenacious and fibrous which makes it difficult and expensive to grind, handle and store. Dry torrefaction improves the physical qualities of the fuel, such as grindability and moisture content. Wet torrefaction removes salts and minerals from the biomass. From the fuel characterisation results it was concluded that wet torrefied G. angustifolia is a high quality solid fuel concerning its elemental composition and heating value, which are then similar to clean wood.

Concerning the combustion simulation trials, the virgin bamboo species show fouling potential similar to herbaceous biomass; dry torrefaction improves the fouling behaviour somewhat, as shown in the fouling factors and deposition propensity results, and wet torrefaction renders a product of high quality that minimises risk of fouling and deposition.

Therefore, despite the lower alkali and chlorine content compared to other herbaceous fuels, the combustion of $100 \%$ virgin but also dry torrefied bamboo is still not recommended before extensive and dedicated assessment of the fouling and slagging risk in pilot scale or with additional detailed lab-scale tests, mainly due to the increased alkali content of the fuel compared to clean wood. In any case, the material needs to be grinded very fine, which is possible with torrefaction. Co-firing at relatively small percentage though is an option as is the standard practice nowadays, due to the counteracting effects of coal ash, minimising the risks of slagging and fouling.

Finally, four other bamboo species were identified as potential candidates for coal substitutes as well, but they were not pre-treated and tested in the laboratory scale combustion facility. Instead, a brief evaluation of their fouling tendency was carried out based on their ash elemental composition using the alkali index and other fuel indicators suggested in 
literature. The calculated values suggest that some bamboo species such as $B$. vulgaris and $D$. strictus should be further assessed to be included in the fuel portfolio of modern pulverised fuel power plants.

\section{Acknowledgements}

The work described in this report was carried out in the frame of the project "Second generation torrefied pellets for the sustainable biomass import form Colombia", funded by Agentschap NL, grant number DBI02006, within the Sustainable Biomass Import program. Partners in the project were: Energy Research Center of the Netherlands (Coordinating partner), Imperial Consultants from Imperial college of London, Colombian Bamboo Society and the Technological University of Pereira (UTP).

\section{List of acronyms and abbreviations}

LHV lower heating value

TGA thermo gravimetric analysis

ICP/AES inductively coupled plasma/atomic emission spectroscopy

IWPB initiative wood pellets buyers

LCS laboratory scale combustor simulator

DP deposition propensity (-)

$m_{\text {dep }} \quad$ ash collected on the deposit probe $(\mathrm{g})$

$m_{\text {ash }} \quad$ ash in the fuel fed (g)

$R_{\mathrm{f}} \quad$ fouling factor $\mathrm{K} \cdot \mathrm{m}^{2} \cdot \mathrm{W}^{-1}$

Specific f.f specific fouling factor $\mathrm{K} \cdot \mathrm{m}^{2} \cdot \mathrm{W}^{-1} \mathrm{~g}^{-1}$

EF enrichment factor (-)

$R_{B / A} \quad$ base to acid ratio (-)

$A_{i} \quad$ alkali index $\mathrm{kg} \cdot \mathrm{GJ}^{-1}$

\section{REFERENCES}

[1] World Energy Council. Bioenergy. In: World energy resources, 2013 survey. World Energy Council; 2013, ISBN 978 094612129 8. p. 7.3, Figure 9.2. Available from: http://www. worldenergy.org/wp-content/uploads/2013/09/Complete_ WER_2013_Survey.pdf. Used by permission of the World Energy Council.

[2] Zwart RWR, Boerrigter H, van der Drift A. The impact of biomass pretreatment on the feasibility of overseas biomass conversion to Fischer-Tropsch products. Energy Fuels 2006;20(5):2192-7.

[3] Kumar A, Ramanuja Rao IV, Sastry C, editors. Bamboo for sustainable development. Proceedings of the 5 th international bamboo congress and the 6th international bamboo workshop; 1998 2-6 November. San José, Costa Rica. V.S.P.: Intl Science (publisher); August 1, 2002. ISBN-10: 9067643572.

[4] Riaño N, Londoño X, Gómez J, López Y. Preliminary data on quantification of the carbon sump effect by G. angustifolia ( $G$. angustifolia Kunth). In: Yiping L, editor. Proceedings of the international workshop on the role of bamboo in Disaster Avoidance; 20016-8 August; Quayaquil, Ecuador. International Network for Bamboo and Rattan (INBAR); 2002. pp. 43-8.
[5] Ch Kleinn, Morales-Hidalgo D. An inventory of Guadua (Guadua angustifolia) bamboo in the Coffee Region of Colombia. Eur J For Res 2006;125(4):361-8.

[6] GFA Consulting Group. Reporte de Auditoria. Corporacion Guadua. Rep. GFA-FM/COC-001333, Colombia; 2005.

[7] Camargo JC, Moreno R, Villota N. Sustainable management of G. angustifolia bamboo forest, Colombia. In: Wit M, van Dam J, editors. Chainsaw milling: supplier to local markets. The Netherlands, Wageningen: Tropenbos International; 2010, ISBN 978-90-5113-094-2. pp. 72-7. Available from: http:// www.etfrn.org/publications/chainsaw + milling: +supplier+to+local+markets.

[8] Chen Wei-Hsin, Du Shan-Wen, Tsai Chien-Hsiung, Wang ZhenYu. Torrefied biomasses in a drop tube furnace to evaluate their utility in blast furnaces. Bioresour Technol 2012;111:433-8.

[9] Rousset P, Aguiar C, Labbé Nicole, Commandré JM. Enhancing the combustible properties of bamboo by torrefaction. Bioresour Technol 2011;102(17):8225-31.

[10] Chen WH, Cheng WY, Lu KM, Huang YP. An evaluation on improvement of pulverized biomass property for solid fuel through torrefaction. Appl Energy 2011;88(11):3636-44.

[11] Kwong PCW, Chao YH, Wang JH, Cheung CW, Kendall G. Cocombustion performance of coal with rice husks and bamboo. Atmos Environ 2007;41(35):7462-72.

[12] IEA Bioenergy Task 32: Biomass combustion and co-firing [Internet]. Utrecht: NL Agency [cited 2014 January 21]. 54 pp. Available from: http://www.ieabcc.nl/

[13] International Renewable Energy Agency (IRENA@) and IEA Energy Technology Systems Analysis Programme (IEAETSAP). Biomass co-firing technology brief E21 [internet]. Philippe Lempp (GIZ) [cited 8 March 2014], 26 pp. Available from:, http://www.irena.org/DocumentDownloads/ Publications/IRENA-ETSAP\%20Tech\%20Brief\%20E21\% 20Biomass\%20Co-firing.pdf; January 2013.

[14] Scurlock JMO. Bamboo: an overlooked biomass resource? Biomass Bioenergy 2000;19(4):229-44.

[15] Verhoeff F, Pels JR, Boersma A, Zwart RWR, Kiel JHA. ECN torrefaction technology heading for demonstration. In: Faulstich M, editor. European biomass Conference and Exhibition 2011: Proceedings of the 19th European biomass Conference and Exhibition (EU BC\&E); 2011 6-10 June; Berlin, International Congress Center Berlin, Germany. Italy: Florence ETA - Renewable Energies; 2011. p. 8.

[16] Koppejan J, Sokhansanj S, Melin S, Madrali S. Status overview of torrefaction technologies [internet]. Final Report. Enschede, The Netherlands: IEA Bioenergy Task 32; 2012 December [cited January 2014]. 54 p. Available from:, http:// www.ieabcc.nl/publications/IEA_Bioenergy_T32_ Torrefaction_review.pdf.

[17] Daza CM, Pels JR, Fryda LE, Zwart RWR. Evaluation of torrefied bamboo for sustainable bioenergy production. In: Gielis J, Potters G, editors. World Bamboo Congress. WBC 2012: Proceedings of the IXth World bamboo Congress (WBC); 2012 $10-15$ April; Antwerp, Belgium. World bamboo organisation, Massachusetts, U.S.A. ISSN 2150 - 11656. p 809-818.

[18] http://www.debco.eu/, Official FP7 Project website DEBCO DEmonstration of large scale Biomass CO firing and supply Chain integration.

[19] European Commission. European biofuels technology platform [internet]. Brussels: Biofuels TP Secretariat; 2014. Energy crops for biofuels [cited March 2014]; [about 2 screens]. Available from:, http://www.biofuelstp.eu., http:// www.biofuelstp.eu/crops.html.

[20] Laborelec GDF. SUEZ [Internet]. Belgium. Laborelec.be [cited 2014 March 10]; [about 2 screens]. Available from:, http:// www.laborelec.be/ENG/services/biomass-analysis/initiativewood-pellet-buyers-iwpb/; 2013. 
[21] Verhoeff F, Adell A, Boersma AR, Pels JR, Lensselink J, Kiel JHA, et al. TorTech: torrefaction as key technology for the production of (solid) fuels from biomass and waste. Project report. Petten, The Netherlands; Biomass, Coal and Environmental research, ECN 201. 82 p. Report No.: ECNE-11-039. Contract No.: EOSLT03017. Sponsored by NL Agency, Ministry of Economic Affairs, Agriculture and Innovation.

[22] Carbo MC, Kalivodova J, Cieplik MK, van der Drift A, Zwart RWR, Kiel JHA. Efficient carbon footprint reduction via entrained flow gasification of coal/torrefied woody biomass blends. Leipzig, Germany. In: 5th International Freiberg Conference on IGCL \& XtL technologies,. Available from:, http://www.gasification-freiberg.org/desktopdefault.aspx/ tabid-103/; 21 May 2012.

[23] Silva AA, Krout A, Biehn C. HCl control using hydrated lime dry sorbent injection. BR-1879. In: Power Plant Air Pollutant Control MEGA Symposium. Proceedings of the power plant air pollutant control MEGA Symposium 2012. August 20-23, 2012. Baltimore, Maryland, U.S.A: Curran Associates, Inc.; April 2013, ISBN 978-1-62276-816-5. p. 1294 (2 vols).

[24] Ogden CA, Ileleji KE, Johnson KD, Wang Q. In-field direct combustion fuel property changes of switchgrass harvested from summer to fall. Fuel Process Technol 2010;91(3):266-71.

[25] Bryers R. Fireside slagging, fouling and high-temperature corrosion of heat transfer surfaces due to impurities in steam-raising fuels. Prog Energy Combust Sci 1996;22(1):29-120.

[26] Jenkins BM, Baxter LL, Miles Jr TR, Miles TR. Combustion properties of biomass. Fuel Process Technol 1998;54:17-46.

[27] Aho M, Gil A, Taipale R, Vainikka P, Vesala H. A pilot-scale fireside deposit study of co-firing Cynara with two coals in a fluidised bed. Fuel 2008;87(1):58-69.

[28] Tortosa Masia A, Buhre B, Gupta R, Wall T. Characterizing ash of biomass and waste. Fuel Process Technol 2007;88(11):1071-81. 


\section{ECN}

Westerduinweg 3

P.O. Box 1

1755 LE Petten

1755 LG Petten

The Netherlands

The Netherlands

$\mathrm{T}+31885154949$

$F+31885158338$

info@ecn.nl

www.ecn.nl 